\title{
Hidden Narratives: The Struggle of Sumba Women in Saving Fresh Water
}

\author{
Titiek Kartika Hendrastiti ${ }^{1}$, Siti Kusujiarti ${ }^{2}$ \\ \{titiek_kartika@unib.ac.id ${ }^{1}$, skusujia@ warren-wilson.edu $^{2}$ \}
}

\begin{abstract}
Dept. of Public Administration, Faculty of Social and Political Sciences, University of Bengkulu, Jl.WR Supratman Bengkulu 38000, Indonesia ${ }^{1}$, The Department of Sociology and Anthropology, Warren Wilson College, Asheville, 701 Warren Wilson Road, Swannanoa, NC 28878, USA ${ }^{2}$
\end{abstract}

\begin{abstract}
This study critically analyzes women's agency in protesting gold mining corporation in Central Sumba, Indonesia. Like other mining areas, the gold mining activities were rejected by the indigenous inhabitants. Narratives of the anti-mining are many, but they did not record the women's involvement. The research applies a postcolonial feminist ethnography method. The imbalance of power relations places women's narratives as hidden. The postcolonial feminist ethnography reveals the hidden struggle of indigenous women; it uncovers various messages of life protection and conservation. Their experience reflects their knowledge of local harmony and resilience. It suggests that women have capacity to clearly explain the root of their anti-mining acts. Women hold the legacy of knowledge to protect natural resources from their female ancestors through spoken language (tutur). Women are not worried about the depletion of gold minerals, but they are more concerned about losing their water sources. Caring for a spring water means establishing themselves as agents for conserving natural resources.
\end{abstract}

Keywords: postcolonial feminist ethnography, sustainable water governance, Sumba Women, hidden narration, women's agency.

\section{Introduction}

Women and Water Issues. Water is human right. Water is a crucial source in human life and development. Adequacy of safe water supply is very urgent for fulfilling drinking and various needs and avoids the effects of diseases such as diarrhea, worm infections, trachoma, chemical contamination such as arsenic and tin. WHO and UNDP and Gender and Water Alliance stated that water adequacy is a basic necessity [32], [28]. WHO recommends that the average population in the world should consume 20-50 liters of water for drinking, cooking and washing. Water requirements per household ranged between 44 and 110 pounds. UNDP Human Development Report and WHO state that improved sanitation is the main response in overcoming gender inequality. Inequality in access to sanitation facilities, hygiene and security is a source of shame, physical discomfort and insecurity for millions of women around the world [27], [32].

The connection between women and water is an important concern in the world for long time. Some documents note that women play a major role in water management. The global recognition of women's involvement in the core water management (as provider, manager, and savior of water) was conducted at the UN Water Conference in Mar del Plate in 1977. The conference was followed by the promotion of gender mainstreaming in water management through the agenda of the International Drinking Water and Sanitation Decade (1981 - 1990), International Conference on Water and the Environment in Dublin (January 1992). Important documents including Agenda 21, Johannesburg Plan of Implementation (Chapter 18), and Decade for Action "Water for Life" (2005 - 2015) provide data and description of women's participation in water management. Women from various regions of developing countries take an active role in water distribution; they also maintain its sustainability. Based on these, Agenda 21 gives recognition of women as agents of water management [27].

Women's and water issues have become a widespread focus on Women's and Gender Studies since the 2000s. Many studies on women and water [14]; [27]; [11]; [13]; [25]; [19] show that women are the main managers of clean water resources and water for productive enterprises. This is especially true for the community of women who live and interact with the ecosystems such as agriculture, 
mining, and plantations in rural areas. But women's involvement and participation in formal water management projects are minimal.

Multinational studies of women and water show that the expansion of water infrastructure in rural areas improves the level of education of children, both for boys and girls [13]. The biggest impact is an improvement in the level of education for girls because they are responsible for fetching water. Data also show that the education level of boys is improving. In Morocco, for example, a clean water supply project has increased the attendance of children to school by 16 percent in four consecutive years [25]. It is clear that the provision of clean water has become a stimulant for improving children's education, especially for girls in rural areas. In other words, the deterioration of water supply in rural areas threatens the level of education and attendance of schools for children. Activities related to the threat of depletion of clean water supplies in rural areas in particular therefore need to be given careful attention. The problem is not only about lack of water for daily needs, but also a threat to the future of children's lives.

Stanford University Report suggests that people who were given certain assignments would develop knowledge related to that particular task. In the developing world, women have the main gendered obligation to manage water, take care of water, and bring it from a spring to home and into the garden, as a result, women develop knowledge about water management and know exactly what kind of water infrastructure development is needed [25]. Women need to be listened to; their thoughts and their knowledge, particularly their knowledge concerning water management need to be considered. Feminist Political Ecology (FPE) suggests the interconnections and importance of gendered environmental knowledge, gendered environmental rights and responsibilities, and gendered environmental politics and grassroot activism [21], [7]. These three elements are pivotal within the context of women's protest against mining activities in Sumba. Women's gendered roles and knowledge in water management play important roles in their activism.

Even though there are many articles about women and water, research focusing on the interconnection between anti-mining women's movements and water in Indonesia remains limited. The conflict of water management between mineral mining corporations and local women is a crucial issue, and it is an ideological point as well. Corporations take clean water for the mineral cleaning process while local women preserve water for their family daily life. Although both parties need clean water; the outcomes of their activities are contradictory, corporate activity creates water source extinction while local women's care for water develops sustainability. This research dwells on these conflicting interests.

Fieldwork for this article was conducted between 2016 - 2018 in Sumba island, Indonesia. Meta data and micro data collected during the fieldwork explain some disadvantages of women and girls when water supply decreases and water quality deteriorate. The mining activities in Sumba lead to drought in the local springs. Before the mining explorations started, water was abundant, water quality was high and spring water in mineral-rich areas were in a very good condition. In the upstream area of the study, which is one of the springs on Sumba Island, the quality of water is very good, clear, healthy, pollution free, and it is sufficient to fulfill the needs of the watershed communities. The arrival of a mining corporation that "plundered" the wealth of gold belonging to the local indigenous people had made the harmonious relations among local communities living around the spring disappear immediately. The extractive activities of gold mining company do not only disrupt the customary management of water, but they also poison the water with mercury and lead used in the process of separating soil and sand from the gold seeds [9]. Women's struggles and agency to face mining activities are the focus of this article. The interconnection between women's gendered roles and their efforts to address the depletion and destruction of their water is analyzed through in-depth observations and interviews to unveil their voices and the hidden complexities of their gendered position, ethnic identities and power relations.

This article is based on participatory observations and interviews using feminist ethnography to unveil these hidden narratives of women who fight against mining activities that create destruction of their water sources. As James Scott suggests unraveling the hidden transcripts of the marginalized groups will help us understand the intricacies of the struggles of those whose voices have not been heard. By using feminist ethnography, the research uncovers women's experiences and perspectives that are otherwise remain marginalized [22]. Women's agency in addressing water issues and their struggles facing the mining activities are analyzed within the context of their active engagement in public discourse. Their public roles, however stems from their gendered roles and responsibilities to provide clean water for their families.

Past studies demonstrate that women's agency is not necessarily enhanced by their involvement in water conservation [2], [14], [4]. Water management is not equivalent to women's empowerment in decision making. In reality power is male or male dominated, and formal water management is largely 
under male's domination. Consequently, water is a source of power. That is why women cannot enter the domain of the formal decision-making process for water governance, because most women are disempowered. Even though women have agencies through their social networks and have strong cultural capital, they are marginalized in the decision-making process. This article addresses women's struggle to express their voices in addressing water issues and in facing the invasion of the mining activities over their water sources to understand how their active involvement in this public issue intersect with their status and empowerment. Feminist ethnography is utilized to uncover and understand these voices and agencies.

\section{Methodology}

This study adopts a postcolonial feminist ethnography because this approach is necessary to: (i) listen to their voices and perspectives on life which have not been widely heard, (ii) reveal knowledge and ideals that are rarely recognized beforehand, (iii) document dissatisfaction, injustice, pride in the identity of local women, (iv) note a limited access from public services and underdevelopment, (v) explain the importance of the position and practices related to customary law pertaining to issues such as children's education, health, and family welfare [3], [15], [23], [12], [6], [10], [9].

Fieldwork covers field-talk, observations, in-depth interviews and tracking memories of women's struggles against a mining corporation. Fieldnotes are strengthened by cross-checking data and validating the meaning of key social concepts. The information is collected through living in the communities. This produces observational records that are useful for understanding the context of women's resistances and the reason for women to organize themselves against the mining corporation and to endure all of the threats [8]; [9].

During the fieldwork performed in Central Sumba, meetings and conversations were conducted with Bapak Desa (village head) who was also the leader of anti-mining movement against the corporation, and a local adat (customary) leader; village officials, and some mothers from various social and class level. This method was conducted as a strategy to get a full picture of women's resistance to the mining corporation and the meaning of their resistance. Researchers also interviewed church leaders, environmental activists, members of women's organizations and NGOs, women's leaders, and local bureaucrats. Interviews with resource persons were also performed. The resource persons are not necessarily key persons who live in the villages, but they are people who are knowledgeable about mining and environmental issues, indigenous and cultural matters, and women's concerns. The fieldwork was conducted for three years and it has produced a fairly comprehensive fieldnotes. However, the researchers are from a non-Sumba ethnic group, some gaps in the field notes may be present due to this different cultural background. Language gap is another important note that needs to be stated in the results of the fieldnotes. Despite these, good rapport was well developed. Cross-checking and validation process were used to ensure the accuracy of the information. The abundant of information collected during each field visit creates a challenge in arranging and compiling analysis for a comprehensive understanding of the cases. To address this challenge, careful reading and analyses of the fieldnotes to identify main themes were conducted to ensure the integrity of the interpretations.

Using postcolonial feminist analysis, the authors find some additional critical issues faced by the women who live in these remote areas. Other than facing conflict over natural resources, the community also faces poor transportation services. Limitations on infrastructure affect their level of education and health, especially their reproductive health status. Poor electricity and lack of other social and public facilities severely affect the villagers. The isolation of the village creates constrains for the advancement of women and put women in an unfavorable position.

Fieldwork was carried out on women's groups in Central Sumba Regency, East Nusa Tenggara. The women groups were involved in the resistance movement protesting a gold mining corporation from 2011 - 2012. The gold mining activities were eventually closed down. However, during the time of the field studies, the women were not sure whether the mining activities would be closed permanently. They were worried that the mining activities would be resumed because the demand for gold at the local and global level remained high. They stayed vigilant on the possibility that the mining corporation would return.

Fieldnotes are based on the reflections of the women's memories involved in the anti-mining movement. Despite the highly stratified society, everyone at all social levels contribute to the success of the anti-gold mining movement. Many women reveal the stories of the movement enthusiastically and vigorously. The memory of the movement is the memory of women's pride in maintaining local life and civilization. 
Women's memories of their involvement in this anti mining movement become an essential part of their identities. The awareness of this identity shows that they are not a community that is easily conquered by global corporations. They are not communities that are dazzled by new forms of civilization that bring unsustainable future. Their awareness of this identity is very strong; it is like a "fire" in social movements. These movements however are influenced by local social stratification and the rapid changes of the status of local elite groups.

\section{Discussions and Results}

3.1 Local and Global Stratifications.

Central Sumba society is a stratified community consisted of three different groups. The first group is Maramba or noble class, the second is Kabihu or free people and is also usually referred to as ordinary people, and the third is ata or the servant group as the lowest rank. Secondary data and interviews with several local sources of this study note that this stratification is still prominent and held firmly by the majority of the groups. This social class affects the customs or adat connected to marriage, dowry, inheritance, social relations, livelihoods, political positions, education, trade, and many things in daily activities [9]. ${ }^{1}$

According to some writers from Sumba, this social stratification is similar to the caste system. The manifestations of the caste system can be clearly observed in daily social relations. This stratification is influenced and legitimized by local religion called Marapu. Even though the influence of Christianity has entered into the life of Sumba people, daily practices based on caste system prevail. Maramba as the elite group tries to maintain their influence and power. They demonstrate these through their behavior and performance such as through their types of clothing, use of jewelry and certain modes of transportation. This elite group also dominates positions at all levels of government offices, has sizable ownership of agricultural land, home (with specific architectural style), animals, woven fabric assets that indicate their social status. Their aristocratic identity can easily be identified further through their names and assets [20], [16], [29], [30], [18].

Several communities in Sumba still follow feudal social system; this stratification system has not been totally transformed yet changes have taken place. The social groups who used to be the noble class now become the upper-class societal members; while the lowest class groups, the "slaves" or ata , turn to become laborers. These lower-class groups are dependent on the upper class while the kabihu or free people is small in size and mainly consisted of migrants. Although caste stratification is no longer used formally, everyday practices remain influenced by this system, this is especially apparent in the custom of marriage, the birth of babies, and the burial of the death.

The megalithic culture is a symbol of nobility. The destruction of the stone of the ancestral tomb by mining activities is a very strong insult to the adat or local customary practices for all members of the local communities. Destruction of the tombstones is a serious act of customary violation. Corollary with that argument, the gold mine has disturbed the harmony of the life of the village communities. It creates the loss of the main identity of the noble class. However, gold mining does not only alter the identity of the elite class, it also affects all other local indigenous social groups. When the corporation extracts gold from the golden hills where ancestral graves are located, it sparked the anger of the indigenous people including the women as part of traditional stakeholders.

The analysis focusing on the connection between power relations at the macro or global level and micro or local communities level demonstrate how gold mining operated by multinational corporation is intricately connected to the local power relations. This global-local relationship based on neo-imperialist relationship turns out to be multilayered in which most women's groups are placed at the bottom of the stratification. Looking at the local social stratification, as mentioned above, this study shows that the lowest ranked group is not even counted or visible in formal social stratification; this group is socially located outside the formal stratification and is known as "slaves" or ata.

The social upheaval of the elite against the corporation, certainly involved the ata because the ata's status is embedded in the noble class position. The deterioration of the local noble families caused by the exploitation of natural resources brings greater hardship for the lowest social layer. Consequently, it is the ata women who experience the worst impact from the mining activities. One of the life-threatening impacts faced by ata women was connected to the decrease of water quality. For the elite, mining activities affect their interests as the leaders and protectors of customs, land and other

\footnotetext{
${ }^{1}$ Although the discussion about social structure in Central Sumba is very interesting, in this paper, the discussion on social structure will focus on changes in structure and social relations related to gold mining conflicts, and how women respond to changes in the environment and living space due to mining activities
} 
village assets. However, there is an internal conflict among the aristocratic community, some are pro mining corporation activities and some are against these activities.

Aristocratic women have important involvement in this social conflict. Some become leaders and fight alongside noble men to protest against the mining corporation. Based on the interviews conducted for this study, the core of the struggle for these women centers around water. Women's struggle against the corporation emphasizes more on efforts to preserve water and agricultural environment than other agenda. Because of their status in the social stratification (and customary rules), these aristocratic women brought along with them their servants (ata group) during their struggle against the corporation. It is not difficult for the noble women to recruit ata groups, because the servants are supposed to be loyal and follow the lead of their master.

For aristocratic women, the mining conflict provides opportunities for learning to show their roles in public arenas and chances to change their lives. The conflict and their involvement in it create "new" public spaces for them, for example, they learn how to lobby and negotiate for their interest, they also develop network with other civilian forces. The study also shows that noble women are aware of their power to fight for a special agenda. However, they are also aware that they need the support of other women. Below, we take a fieldtalk narrative from a noble mama:

"... satu jawaban saya, kalau tidak ada air, manusia tidak bisa bergerak. Mulai dari kebutuhan di dalam rumah, dan irigasi sawah serta hidup hewan, semua membutuhkan kecukupan air, dan itu adalah tanggung jawab perempuan. Air itu harus ada berkesinambungan, air bersih perlu dipertahankan" [9]

("... my important point: if there is no water, humans cannot move. Water is needed inside the house as well as outside. It needed for irrigation of the rice fields and animal life. All activities need adequate water, and that is the responsibility of women. Clean water must be sustainable)

Their experiences in fighting the mining activities and to win this battle have shown them that the strength of this movement stems from women's ability to unify different groups of women from various social strata. It also creates a realization among the aristocratic women that the persistent support of the servants is proven to be an important element in driving out the power of foreign capital. This is one of the social changes stemming from the impact of mining conflicts for the aristocratic women.

The lives of women from ata groups in the context of these mining conflicts turned out to be very different from what was 'hypothesized' by the research team. The research team obtained an overview of ata women's daily social relations with their masters from references and narratives of secondary sources. According to these secondary sources ata women tend to just follow their masters' lead. However, the picture seems to be different in the conflict situations, especially during demonstrations against the mining activities.

Many of the ata narratives describe their active involvement in preparing for the demonstration, during the demonstration, and the "evaluation" afterwards. An important reason for ata to engage in the gold mining conflict is:

“...bila akan ada sidang perkara tambang, kami siap untuk ikut serta. Karena banyak keluarga yang ikut demo di luar ruang sidang, lebih dari 100 orang, jadi kami membantu memasak, dan menyiapkan keperluan demo. Itu pengalaman yang baru” [9]

" ... if there would be a trial, we were ready to participate. Because members of the families took part in the demonstration outside a court room, they were more than 100 people, so we helped cooking and preparing other rally needs. It was a new experience"

This phenomenon shows that the ata group manages to create more space and demonstrate their actions during the conflict. They are able to show their thoughts and skills to the public. In addition to their loyalty to the masters, this group had a chance to demonstrate publicly that as a group they have significant role in defending their homeland and their customs. In particular, the struggle against the mining activities shows that all women regardless of their status have a core interest in water sustainability.

3.2 The Meaning of Water for Sumba Community.

Sumba is Humba, meaning water. From the field-talk and thematic group discussions, the meaning of water is recorded from the perspective of indigenous women. Mama Desa Tua, who also became a leader in the anti-mining movement after her husband was arrested, became a key resource person during the field research. As soon as she started being invited to talk about water, her first sentence was utterly philosophical. The basic meaning of water, according to her: "... one of my 
answers, if there is no water, humans cannot move ...". Furthermore, she stressed, as a Sumba woman, water is the first element; water is the source of life. Water is a source, that it is needed continuously.

Mama Desa Tua firmly says that based on indigenous cosmology it is known that Sumba's female identity is centered around water agency. Water is the source of life; women are the core of the customary rules of Sumba, or Humba, or water. In accordance with the memory of the people of Sumba, it is related to mamoli; mamoli is a symbol of womb, and fertility. Following this assumption, the damage and scarcity of water (by any reason) will threaten the womb and fertility of women. It also means a serious threat to the lives of the entire community.

Furthermore, other mothers add that water is a daily family need: for drinking, bathing, cooking, washing clothes, and all activities that (socially) become the responsibility of women at home. Water is also the main element of other essential activities such as for irrigating rice fields, drinking and bathing animals. Therefore, water needs to be maintained continuously, so that water is not polluted. All of these activities are the responsibility of women. The field-talk notes demonstrate that women actually have agencies in water governance yet this agency may not be necessarily recognized formally.

In the context of gold mines, the extraction processes require a lot of water and emit hazardous waste water. It is the main reason for women to refuse the mining activities. For women from Central Sumba the paradigm created by mining companies suggesting that mining activities create or improve the welfare of the communities is too easy to break and reject. These women are water experts, water managers who can easily assess water quality and see how the mining activities adversely affect their water. According to them, the quality of spring and river water is far more important compared to the promise of wealth by the corporation.

The gold exploration, which took place over a period of one year, brought many disasters. The main disasters created by the mining companies mentioned by the women are (i) pollution of water and depletion of water sources. The spring they have in the village, located in some hamlets, which never dried up - in a short time it was depleted by the process of washing gold beans. (ii) destruction of the environment in the village and its surroundings; water pollution directly kills animals and causes skin irritation among children. Mamas also noted that a lot of diseases and disorders are developed among community members because they consume water from corporate extraction activities. (iii) damage to the megalithic stone of the ancestral tombs; the Sumba people did not let go of the ancient megalithic traditions of their ancestral tombs. ${ }^{2}$ These disasters do not only affect their physical conditions but also impact their culture and identities.

Women's reproductive experiences provide important knowledge about water including maintaining and caring for water, and dealing with all threats of water source damages. Women's reproductive work cannot take place without water. This study shows that women's voices and resistance play essential role in the conflict for water. Women organize their protests as a response to the danger faced by the springs. This water issue then becomes the core of women's identity in rejecting gold mines. They suggest that they need to fight and defend the village from all mining activities because these activities destroy their live and livelihood. Practically, water is an important element for animal life and because animals are the identity of Sumba women, then water is their identity too. Simply stated, Mama Desa explained that animals eat grass, grass must have water, then water is a woman's identity.

What is the relationship between water and animals? Animal is an important element in Sumba cosmology. Animals are the identity of Sumba, in traditional wedding ceremony, animal bélis ${ }^{3}$ are the main requirements besides golden mamoli $^{4}$ and woven fabrics (tenun). Moreover, death and burial ceremonies also require slaughtering animals or the spills of animal blood. For women, animal is a central element. Animal is a symbol of the status of women, especially noble women "... no animals, no deals, no agreement to take the bride". Bélis does not mean individuals; bélis has a collective meaning for the clan, it has important cultural meaning for the kinship and creates significant social ties that are very important on Sumba Island.

\footnotetext{
${ }^{2}$ The ancient megalithic tradition, for example a ritual of pulling grave stones with heavy stones from the hills to the location of the traditional house complex can be seen in http://www.youtube.com/watch?u=pWHpdxhjo-M. A preservation of grave stones as a cultural heritage can also be seen in http://www.pesona.indonesia.travel/.../kubur-batu-sumba-lestarinya-buday-megalitik

${ }^{3}$ Belis is a kind of dowry. Belis is given by the groom's family to the bride's family. Belis consists of animals such as buffalo and horses; the groom family brings woven fabrics, and a gold mamuli pendant. The higher the nobility position of the bride's family is, the more the number of animals required, it can reach in hundreds of animals. The two families are making negotiation several times before deciding on the number of belis animals.

${ }^{4}$ Mamoli is a symbol of the female reproductive organs, a symbol of female fertility, and a source of life for the people of Sumba. Mammoli can take the form of pendants, earrings, and other jewelry; including a locket. Mamoli forms can also be woven motifs, building motifs, statues.
} 
Gold mining corporation did not directly take water, they took gold. With gold extraction process, they drill gold sand and process mineral sand by washing the sand with clean water from the mining location. At the end, the source of clean water for the community is also polluted and the springs become dry. On the other hand, for Mama, they know exactly that there is a connection between gold mines and water. The main goal for rejecting the corporation is protecting water. As illustrated above, Sumba women were the first to know the impact of the gold extraction business. They are worried about the declining quality and availability of spring from upstream water sources to downstream rivers. They clearly illustrate the risks faced by the village community and other villages in the valley. The gold extraction business would force the community around the river to move or be displaced from their ancestral land.

After the mining corporation stopped its operation, water quality is improving; the residents can live in peace again, and the ecosystem is saved. Animals and plants return to life well and do not consume polluted water. Clean and healthy water becomes the core of life, for humans, animals and plants. Water guarantees the stability and harmony of life in the village. This harmonious relationship and values are symbolized through the WaiHumba festival.

\subsection{Wai Humba Festival: Community Act for Sustainability.}

The Sumba communities strengthen their strives against the mining corporation in their own way. Women are part of the customary efforts to fortify communities from the island's natural resources destructions. Their unique efforts are demonstrated through the preservation of adat, solid kinship system, the maintenance of the marriage system, the protection of ancient tombstone megalithic traditions, and the continuation of traditional ceremonies - all of these preservations are put together in an annual water festival, called Wai Humba. ${ }^{5}$

Wai Humba festival symbolizes Sumba people's resistance to all types of exploitation of natural resources on Humba lands. Because Humba means water, the symbol of resistance from Humba land is called Wai Humba. Wai Humba is a discourse to restore traditional knowledge in preserving the nature of Sumba. The means to strengthen the value of traditional Sumba culture is through the symbol of water.

Wai Humba Festival is a movement. Wai is synonymous to water; while Humba also means water. It is told in the documentation about Wai Humba, that traditionally, in Marapu religion, the people of Sumba perform ritual ceremonies praying at spring sources - which is in the Marapu tradition called Kalarat Wai. ${ }^{6}$

The Wai Humba Festival is also referred to as the Three Mountain Festival (which are the locations of springs on Sumba Island). They are namely: Wanggameti, Tana Daru, and Yawilla. Wanggameti is located in East Sumba, the name means driving away from death. This is because Wanggameti gives water, food, wood and medicinal plants to the community. Tana Daru, located in Central Sumba and West Sumba, also provides water, food, wood and medicine. Lastly, Yawilla, located in Southwest Sumba, guarantees the availability of water and living resources for the community.

The Wai Humba Festival began in 2012 when they were protesting against the mining activities. Every festival always has series of activities, which in essence strengthen the customary practices and awareness of preserving natural resources, especially safeguarding water. Various activities at the Wai Humba festival include traditional ceremonies or rituals, customary reflections and meetings, discussions, horse exhibitions and attractions, local food exhibitions, organic farming, traditional arts and games, sharing discussions about environmental conservation, water entertainment, environmental warrior awards, and much more.

Women are involved in all Wai Humba ceremonies; they are determined to use the Wai Humba forum to strengthen their socio-cultural position as a community group who manages water. Wai Humba is a way for women to publicly demonstrate their strategic positions in society. Water management is an instrument to uncover their social invisibility. Wai Humba provides a new public space for Sumba women to express their agency in conserving water and other natural resources and in opposing any power that destroy these. This public space has essential cultural meanings to be captured, so that the people of Sumba have more balanced and sustainable live and livelihood. Even

\footnotetext{
${ }^{5}$ Notes of the Wai Humba Festival can be seen at: http://www.jatam.org ; http://www.kombinasi.net/festival-waihumba-parade-komunitas-lokal-tolak-tambang

${ }^{6}$ Wai means water, so the people of Sumba Island named their district capital Wai as their front word, for example Waingapu for the capital of East Sumba Regency, Waibakul for the capital of Central Sumba Regency, Waikabubak for the capital of West Sumba Regency, Waitabula for the capital of Southwest Sumba Regency.
} 
though the gold mining corporation has left their Hills, women's attitudes remain firm, namely rejecting the mineral mining.

\subsection{Prospects for New Public Spaces.}

The study on mining conflicts in Central Sumba shows that women and water in mining conflicts have its own characteristics. Among the community members themselves, there are different values in responding to mining conflicts. Besides being different, women's response to mining activities is more specific. It is related to the uniqueness of women's life experiences. Women's response to mining activities is related to the threats of the damage of their bodies, especially the reproductive problems and the daily workload that endanger the body.

This study shows that women's resistance and rejection of extractive activities carried out by corporations are related to water. The issue of women, water and mining is intertwined with patriarchal cultural forms and norms, all cases have such characteristics; this finding also occurred at other mining sites, for example Mollo, Kendeng, Wongsorejo, Kulon Progo, Penago Baru, and Praikaroku Jangga, and other cases [1], [10], [9].

As a comparation, Parker et al. study with the theme of "Gender, Agriculture, and Water Insecurity" shows that when natural damage, drought, and crop failures hit the community, women bear the heaviest risk. In every farming community, women are informally involved in water management. That's why in anticipating various possibilities of nature that cause water shortages, women immediately look for strategies to overcome the water problem [19].

Asriani's study discusses the resistance of Mollo women in the Mutis Mountains against marble mining; the study describes women's struggle to care for the body and nature. Her study shows that water is one of the reasons of their resistance. Mining has become one of the sources of environmental injustices; because mining activities endanger the opportunity for people's lives and isolate the lives of women as the keepers of natural environments [1].

Women are not homogeneous; women everywhere are multicultural agents, they are keepers of the environment. Women's social orientation grows in accordance with the original expectations of the community where women are put in charge of fulfilling the need of family and community food. Maintenance of biodiversity becomes an integral part of women's identity. Women live and are lived by the nature; among the main natural elements for female life is water. So, water is a source of identity for women. When water quality is affected, women's identity is also altered. For example, in Yogyakarta, Indonesia when mining replaces activity on dry agricultural lands, women's identity as farmers also disappear Nugroho [17]. In Bengkulu, another part of Indonesia, the iron sand mining has destroyed coastal farms and eliminated mussels utilized by women [10]. One of the most important issues creating the identity of women's protest against corporation is water partly because water plays pivotal roles in their reproductive life experiences, namely menstruation, pregnancy, and childbirth.

Moreover, the fieldnotes of this study show that women's activities such as farming, weaving, raising livestock, planting chilies and eggplant on the yard are not considered as productive activities. Because these women's works are not performed in large scale even though these works are pivotal in fulfilling daily household needs. The concept of work is always referred to the commercial value of the production, to be recognized as productive work, it has to make money. This research shows that mamas in Sumba try to fulfill the main needs to feed their families. Extra production is sold to finance marriage celebrations, death and other traditional ceremonies. This demonstrates that the women's focus is on ensuring food availability for families and communities because they believe that their ancestors inherit a spiritual energy to maintain food sovereignty.

Another finding of this study reveals that in the cases of mine conflicts, the people who organize themselves against the mining activities are portrayed as "enemies" of the corporation, government", and security forces [10], [17], [9]. Those three parties formed an alliance with different motives and interests. Corporations, who have economic resources, collaborate with government officials - as authoritative power over land management and deployment of bureaucracy from top to lower levels. The security apparatus completes the alliance in order to deflate and intimidate the people's power.

The pro-mining groups creates an image and discourse of mining as a symbol of prosperity. As an anti-thesis, women tend to reject this idea because women have a critical awareness of the knowledge they have through their everyday life experiences and these experiences show the opposite. For many local communities, mining is not prosperity, mining is a loss and destruction of their ecosystem. It is the end of their "civilization".

The resistance of local women has their own identity, they define their own struggle. For example, in Seluma, Bengkulu, the main reason for women's struggle against the iron sand mining corporation is to guard ancestral graves, mussels and coastal agriculture [10]. While in the coastal communities of Yogya, women identify their resistance as efforts to guard their grassland [17]. 
This study shows that the struggle of women to reject the gold mine is a struggle to defend their living space. Living space encompasses a life span beyond the limits of the physical life of nature, it crosses the boundaries of the integrated social, cultural, knowledge and hopes of women. Based on this study, the figure below describes the main factors that have instrumental roles in shaping women's struggles against mining activities.

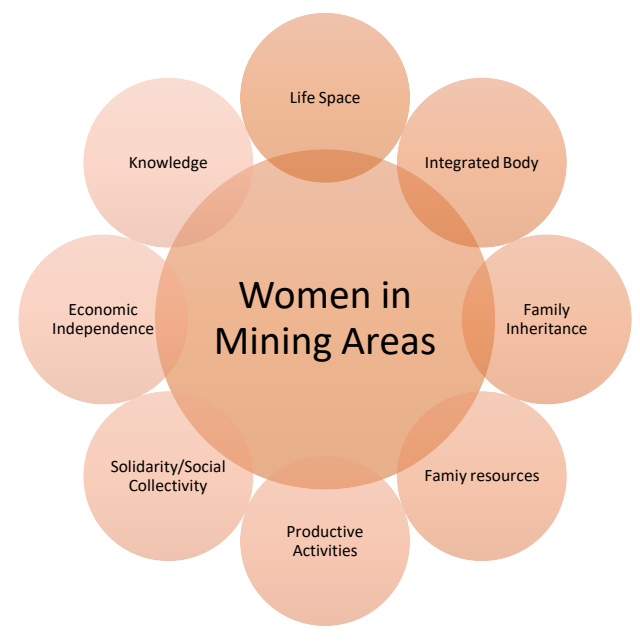

Fig.1: Women's Identity of Anti- Mining

The research findings above show that there are various influences that build women's identity as agent of creating local public agenda through their resistance of mining activities. Their power in creating and demonstrating public resistance and conflict over natural resources is described in the interrelated factors portrayed in the figure. This study helps us unlock the importance of women's involvement in mining conflicts. Using qualitative data, it reveals the voices of women, especially lower-class women that have been silenced and buried under more vocal and dominant discourse. This study also records the important contribution of women in protecting local assets and investments.

\section{Conclusions}

Water is an integral part of women's identity. The memory of water management is carried out in oral language (tutur). The narratives on water is part of indigenous knowledge in the context of natural and social conservation. Furthermore, based on the results of studies from various locations, especially in rural areas, indigenous women do not live apart from water. Women become agents in water management and social changes. They are the "experts" in taking care of water quality due to their gendered roles and status. Women are the first to respond when water conditions are threatened. It can be suggested that the memory of a woman's body is a memory of water.

Women feel the threat to water and water sources, the damage to rice fields and gardens, the poisoning from cleaning minerals, and changes in the environment. The sense from their gendered experience gives clues to the existence of a cultural threat to their lives and identities. The destruction of water sources leads to the annihilation or damage of their bodies. This study shows that female narratives of water reveal the existence of a new faceless form of oppression, a new-imperialism that transform the identity of indigenous women.

Feminist postcolonial discourse and methodology are pivotal in uncovering socio-economic inequality in mineral extraction operations. The analyses uncovers women's voices and narratives in mining issues. It also explains the intersectionality of women's interest with the interests of the state at local-national-global levels, and with the economic and political forces surrounded their movements.

Postcolonial feminist ethnography provides a wider space for local women's communities who involve in extractive conflicts to voice the core elements of their resistance. This is often called as a third space. Fieldwork and postcolonial feminist ethnographic analysis allow researchers to reveal the vulnerability of women in social, cultural and political systems. It is known as a subaltern community who are having a heterogenous identity. The images of the deterioration of women's status at the local level lead us to see the deterioration of women's positions at wider levels. But, the approach also shows that women have their agencies. 
Cases of women's activism in most mining areas are hidden. Impoverishment due to the damage of the mining communities has not been sufficiently addressed. The corporation and local supporters only see the extractive operations as mining activities, they neglect local culture and practices, social institutions, and local politics. For counter-mining groups, including women, extractive operation is a process of cultural destruction and a shift in natural resource governance.

This study demonstrates that the struggle of Sumba women against mining corporations is a struggle to reclaim and maintain life and to care for the living space. The movement has proven that their main goal is to defend water; hence the movement's identity is broader than just rejecting mine operations. The movement refers to the identity of the postcolonial community dealing with the power of global business and the threat of impoverishment of the natural resources and cultural identity.

Acknowledgement. This article is written based on a multiyear research entitled "Reconstruction of Village Sovereignty, Identity, and Nationalism in Mining Conflict Areas: A Study of Women's Engagement in Socio-Economic Engineered Recovery”. Thanks go to Directorate of Research and Community Service, Directorate General of Research and Development, Ministry of Research, Technology and Higher Education Republic of Indonesia. Directorate of Research and Community Service, Directorate General of Research and Development has funded the research for three years, 2016 - 2018, in accordance with the last Research Contract Letter Number: 539 / UN30.15 / LT / 2018.

\section{References}

[1] Asriani, Desintha D. 2015. Perempuan Mollo Merawat Tubuh dan Alam: Aleta Baun, Paha Nifu, dan Pegunungan Mutis. In Dewi Candraningrum and Ariati Ina Restiani Hunga (eds.). Ekofeminisme III: Tambang, Perubahan Iklim, dan Memori Rahim. Yogyakarta: Jalasutra, 125-140.

[2] Boateng, Juliette D., C. K. Brown, and E. Y. Tenkorang. 2013. Gender and Water Management Practices in Ghana. Journal of Environment and Earth Science ISSN 2224-3216 (Paper) ISSN 2225-0948 (Online), 3(5). Retrieved from www.iiste.org

[3] Brooks, Ann. 1997. Postfeminisms. New York: Routledge.

[4] Choudhury, Runti, Chandan Mahanta. 2018. Scope and Challenges of Sustainable Drinking Water Management in Assam. In Urban Ecology, Water Quality and Climate Change. DOI: 10.1007/978-3-319-74494$0 \_30$

[5] Demartoto, Argyo. 2014. Ancaman Limbah Batik Sragen bagi Perempuan: Kajian Ekofeminisme Transformatif. In Dewi Candraningrum (ed.). Ekofeminisme II: Narasi Iman, Mitos, Air dan Tanah. Jakarta: Jalasutra, 213-228.

[6] Elabor-Idemudia, Patience. 2004. Participatory Research: A Tool in the Production of Knowledge in Development Discourse. In Kriemild Saunders (ed.). Feminist Post-Development Thought: Rethinking Modernity, Poscolonialism and Representation. London-New York: Zed Book, 227-242.

[7] Elmihirst, Rebecca. 2011. Introducing New Feminist Political Ecologies. Geoforum, 42, 129-132.

[8] Hendrastiti, Titiek K. 2019. Oral Story of Women's Anti-mining Group in Sumba: A Narrative of Subaltern Movement for Food Sovereignty. Indonesian Feminist Journal, Jurnal Perempuan, 24(12), 1-12. Retrieved from www.jurnalperempuan.org

[9] Hendrastiti, Titiek K. 2018. Ragam Identitas Perempuan Ragam Identitas Perempuan Bukan Bayang-Bayang: Menguatkan Konstruksi Nasionalisme. Jakarta: Yayasan Pustaka Obor Indonesia.

[10] Hendrastiti, Titiek K. 2014. Perempuan Lokal vs Tambang Pasir Besi Global. Jakarta: Yayasan Pustaka Obor Indonesia.

[11] Hunter, P., MacDonals, A., \& Carter, R. 2010. Water Supply and Health. Public Library of Science (PLoS) Medicine, 7 (11), 1-9.

[12] Katrak, Ketu H. 2008. Decolonizing Culture: Toward A Theory for Postcolonial Women's Texts. In Bill Ashcroft, Gareth Griffiths, dan Helen Tiffin (eds.), The Post Colonial Studies Reader. Second Edition. London-New York: Routledge, 239-242.

[13] Koolwal, G., \& Van de Walle, D. 2010. Access to Water, Women's Work and Child Outcomes. Economic Development and Cultural Change. Working Paper Series. Retrieved from https://www.researchgate.net/publication Access to Water Women Work and Child Outcomes

[14] Michael, Benedict P. 1998. The Role of Women in Water Resources Management: The Tanzania Case. International Journal of Water Resources Development .14 (4), 499-504

[15] Mohanty, Chandra Talpade. 1988. Under Western Eyes: Feminist Scholarship and Colonial Discourses. Research Article. SAGE Journal. Retrived from https://doi.org/10.1057/fr.1988.42

[16] Nona 2407. 2011. Hamba Perempuan di Sumba Timur. Retrived from http://www.nona2407.blogspot.co.id/2011/04hamba-perempuan-di-sumba-timur . Uploaded on Sunday 17 April 2011

[17] Nugroho, Argoposo C. 2015. Bertani di Atas Pasir Pesisir Pantai Selatan Yogyakarta: Studi Kasus Perempuan Melawan Tambang Pasir Besi. In Dewi Candraningrum and Ariati Ina Restiani Hunga (eds.), Ekofeminisme III: Tambang, Perubahan Iklim, dan Memori Rahim. Yogyakarta: Jalasutra, 103-124. 
[18] Nugrohowardhani, R.L.K.R. 2014. Perlawanan Perempuan dalm Industri Kapas: Kajian Kerusakan Lingkungan di Sumba Timur. Indonesian Feminist Journal, Jurnal Perempuan, 19 (1), 87-114.

[19] Parker, Helen, Nathaniel Mason, Naomi Oates, Roger Calow, William Chadza, Eva Ludi. 2016. Gender, Agriculture, and Water Insecurity. Retrived from http://odi.org

[20] Renda, T. 2012. Studi Kasus tentang Perubahan Sosial di Sumba Timur terhadap Persyaratan Gelar Kebangsawanan. Retrived from www.repository.uksw.edu/bitstream/297412/T2 752011041

[21] Rocheleau, Dianne, Barbara Thomas-Slayter, Esther Wangari. 1996. Feminist Political Ecology: Global Issues and Local Experience. New York, NY: Routledge.

[22] Scott, James. 1992. Domination and the Arts of Resistance. New Haven and London: Yale University Press.

[23] Spivak, Gayatri Chakravorty. 2008. Can the Subaltern Speak ?. In Bill Ashcroft, Gareth Griffiths, dan Helen Tiffin (eds.). The Post Colonial Studies Reader. Second Edition. London-New York: Routledge, 28-37.

[24] Srdjan, Mirkic, Tina Johson, Michael Rose. 2010. The World Women 2010 - Trends and Statistics. UN Statistic Division. Retrive from https://www.un.org/the-worlds-women-2010-trends-and-statistics

[25] Standford University Report. 2011. Gendered Innovations, Water Infrastructure Reseach and Design. Retrived from www.genderedinnovation.stanford.edu

[26] Thai, Nguyen Van. 2018. Women and Water Management: A case study from the rural communities in Vietnam. American Journal of Qualitative Research, ISSN: 2576-2141, 2 (1), 118-161. Retrived from http://www.ajqr.org/

[27] UNDP, Human Development Report 2006 . 2006. Beyond Scarcity: Power, Poverty And The Global Water Crisis. United Nations Development Programme (UNDP). Retrieved from hdr.undp.org > sites > default > files , reports > hdr06-complete

[28] UNDP and Gender and Water Alliance (GWA). 2006. Mainstreaming Gender in Water Management, Resource Guide, United Nations Development Programme (UNDP). Retrived from https://www.preventionweb.net > organizations

[29] Wara, Yanuarius Lende. 2012. Tradisi Belis dalam Upacara Perkawinan dan Perubahan Sosial, Ekonomi Masyarakat Sumba Barat Daya. Retrived from www.repository.uksw.edu/bitstream/.../Tradisi Belis dalam Upacara Perkawinan dan Perubahan Sosial, Ekonomi Masyarakat Sumba Barat Daya.pdf

[30] Wara, Yanuarius Lende dan Purwiyastuti. 2013. Pergeseran Makna Belis dalam Adat Perkawinan Masyarakat Sumba. Retrived from www.repository.uksw.edu/bitstream/123456789/6410/2/PROS Yanuarius

[31] Watts, Susan. 2004. Women, Water Management, and Health, Emerging Infections Disease, 10 (11), 20252026. Retrived from www.cdc.gov/eid,

[32] WHO. 2010. Progress On Sanitation And Drinking Water: 2010 Update, WHO/UNICEF Joint Monitoring Programme (JMP). Retrived from https://www.who.int/water sanitation health monitoring key terms 